\title{
Respon Pembungaan Globba leucantha var. bicolor Holttum Terhadap Volume Pemberian Air dan Pupuk NPK
}

\section{Flowering Response Globba leucantha var. bicolor Holttum Toward The Volume of Water Giving and NPK Fertilizer}

\author{
Widianti $^{1 *}$, Nurcahyo Widyo Daru Saputro ${ }^{2}$, Wagiono ${ }^{2}$, Rika Yayu Agustini² \\ ${ }^{1}$ Program Studi Agroteknologi Fakultas Pertanian, Universitas Singaperbangsa Karawang. \\ ${ }^{2}$ Program Studi Agroteknologi Fakultas Pertanian, Universitas Singaperbangsa Karawang \\ *E-mail: widyapurly@gmail.com
}

\begin{abstract}
This study aims to determine the response of Globba leucantha plant flowering to the provision of water and NPK fertilizer. The study was conducted for 3 months September until November 2020 in a screen house located in the Dayeuhluhur sub-district, Cilacap district, Central Java. The method used was a single factor randomized design of 12 treatments repeated 3 times consisting of water and NPK fertilizer: 100\% Crop Water Consumption (CWC) without fertilizer; $100 \%$ CWC fertilizer + 2 grams / plant; $100 \%$ CWC fertilizer + 4 grams / plant; $80 \%$ CWC without fertilizer; $40 \%$ CWC + fertilizer 2 grams / plant; $80 \%$ CWC + fertilizer 4 grams / plant; $60 \%$ CWC without fertilizer; $60 \%$ CWC + fertilizer 2 grams / plant; $60 \%$ CWC + fertilizer 4 grams / plant; $40 \%$ CWC without fertilizer; $40 \%$ CWC + fertilizer 2 grams / plant; $40 \% C W C+$ fertilizer 4 grams / plant. The results showed that the volume treatment of water and NPK fertilizer had no significant effect on the length of the panicles and the number of flowers per panicle produced.
\end{abstract}

Keywords: Flowering, Globba leucantha, NPK, Water

Disubmit : 13 Januari 2021, Diterima: 14 Januari 2021, Disetujui : 05 April 2021

\section{PENDAHULUAN}

Beberapa tumbuhan dari genus Zingiberaceae salah satunya tanaman Globba memiliki perbungaan dan bunga yang sangat bervariasi. Variasi ini dapat dilihat dari bentuk perbungaan, posisi tangkai perbungaan, warna daun gagang, dan warna bibir bunga (Handayani, 2018). (Phantong et al., 2018) menyatakan bahwa di Thailand tanaman Globba ini memiliki nilai permintaan yang tinggi karena bentuk pembungaannya yang menarik. Namun budidaya tanaman ini masih terbatas karena tingkat perbanyakan rendah dan hanya tergantung musim saja.

(Nontasit et al., 2015) menyebutkan beberapa spesies Globba memiliki habitat berupa hutan bambu dan kebun tanaman campuran terdapat di area sekitar air terjun. Habitat spesies Globba leucantha ditemukan di hutan tropis lembab, semi ternaungi, memerlukan cahaya dan memerlukan banyak air (National parks, 2019) .Air diperlukan tanaman untuk dapat tumbuh dengan optimal sehingga dapat menghasilkan produksi yang maksimal (Abdurachman et al., 2005). Menurut (Gatabazi et al., 2019) air adalah salah satu komponen penting dalam produksi tanaman yang dapat mempengaruhi hasil panen. Banyaknya air dan ketersediaannya akan mempengaruhi aktivitas penyerapan hara oleh akar tanaman sehingga berpengaruh pada peningkatan pertumbuhan tanaman (Pangesti, Herlina and Suminarti, 2017). Pemberian air cukup diberikan sekitar 60-80\% dari air tersedia tergantung jenis tanaman (Abdurachman et al., 2005). 
Globba leucantha merupakan tanaman baru yang akan didomestikasi sebagai tanaman hias bunga. Pemberian pupuk dengan kandungan fosfor dan kalium tinggi pada konsentrasi yang tepat dapat memacu pembungaan pada tanaman (Ula et al,. 2019). Hal tersebut terjadi karena ketersediaan unsur hara P dapat menjadi faktor pembatas untuk reproduksi tanaman tertentu, penambahan unsur $\mathrm{P}$ dapat merangsang produksi kuncup bunga (Petraglia et al., 2014). Salah satu jenis pupuk NPK majemuk lengkap yang memiliki kandungan fosfor tinggi adalah pupuk NPK Growmore (10:55:10). Berdasarkan penelitian Mpapa et al., (2018) metabolisme tanaman akan berjalan dengan baik apabila unsur-unsur hara dalam tanah tersedia dalam jumlah yang cukup, maka diperlukan nutrisi bagi tanaman untuk menunjang keberlangsungan hidupnya. Pemberian pupuk NPK Growmore dengan dosis 2 gram/liter air dapat mencukupi kebutuhan unsur hara makro dan mikro tanaman (Halisah, 2013). Pupuk NPK dalam budidaya tanaman jahe diberikan sebanyak $125 \mathrm{~kg} / \mathrm{ha}$ atau sekitar 2 gram/tanaman (Jalil et al,. 2016). Penelitian ini bertujuan untuk mengetahui respon pembungaan tanaman Globba leucantha var bicolor Holttum terhadap volume pemberian air dan pupuk NPK.

\section{METODE PENELITIAN}

Penelitian dilaksanakan di Rumah kasa yang berlokasi di Desa Panulisan Barat Kecamatan Dayeuhluhur Kabupaten Cilacap Jawa Tengah pada bulan September sampai dengan bulan November 2020.

Alat dan Bahan yang digunakan berupa polybag $(20 \times 10 \mathrm{~cm}),(15 \times 7,5 \mathrm{~cm})$, terpal, ayakan tanah, cangkul, wadah koleksi, alat siram, timbangan, gelas ukur, meteran, jangka sorong, termohigrometer, kamera handphone, alat tulis, Globba leucantha, tanah top soil, pupuk NPK majemuk Growmore (10:55:10) dan air.

Metode yang digunakan Rancangan Acak Kelompok faktor tunggal sebanyak 12 perlakuan yang diulang 3 kali terdiri dari pemberian air yang dihitung berdasarkan kebutuhan air tanaman (KAT) dan pupuk NPK Growmore. Kebutuhan air tanaman dihitung berdasarkan Metode Blaney Cridle dengan rumus:
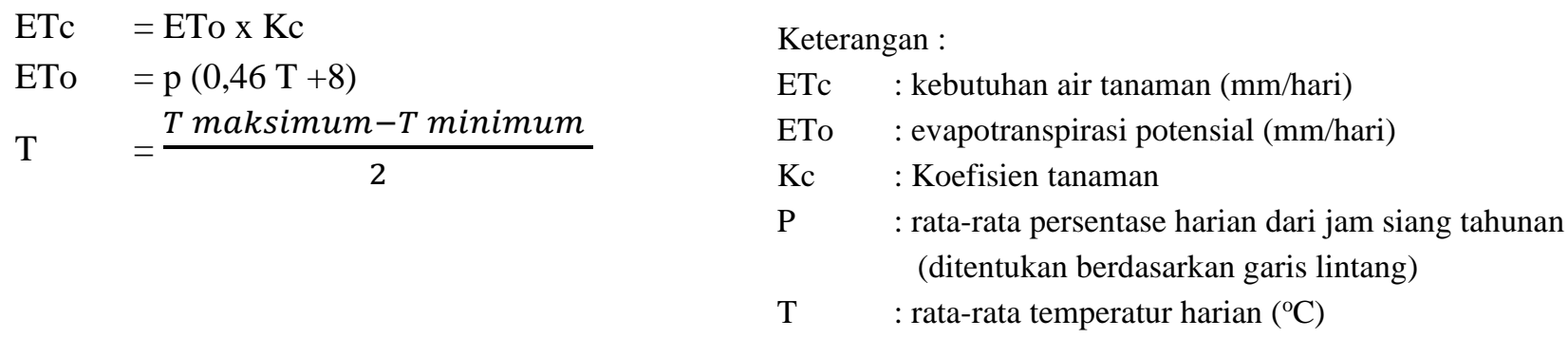

Rancangan perlakuan yang diberikan yaitu : $100 \%$ KAT tanpa pupuk; $100 \%$ KAT + pupuk 2 gram/ tanaman; 100\% KAT+ pupuk 4 gram/tanaman; 80\% KAT tanpa pupuk; 40\% KAT + pupuk 2 gram/ tanaman; $80 \% \mathrm{KAT}+$ pupuk $4 \mathrm{gram} / \mathrm{tanaman} ; 60 \% \mathrm{KAT}$ tanpa pupuk; 60\% KAT + pupuk $2 \mathrm{gram} /$ tanaman; $60 \%$ $\mathrm{KAT}+$ pupuk $4 \mathrm{gram} /$ tanaman; 40\% KAT tanpa pupuk; 40\% KAT + pupuk $2 \mathrm{gram} /$ tanaman; $40 \% \mathrm{KAT}+$ pupuk $4 \mathrm{gram} /$ tanaman. Data diolah menggunakan analisis ragam uji $\mathrm{F}$ taraf 5\% dan uji lanjut DMRT taraf $5 \%$.

Tahapan penelitian berupa persiapan media, koleksi tanaman dari alam, adaptasi tanaman selama 7 hari, penanaman, penyiraman, penyulaman, aplikasi pupuk NPK Growmore pada umur 15 hst, 25 hst, 35 hst dan 45 hst, pengendalian OPT, pengamatan.

Parameter utama yang diamati berupa fenologi bunga, panjang malai bunga dan jumlah bunga per malai, sedangkan parameter penunjang berupa komponen pertumbuhan vegetative meliputi jumlah daun, jumlah anakan,dan tinggi tanaman.

\section{HASIL DAN PEMBAHASAN}

\section{Pertumbuhan Vegetatif}

Berdasarkan Tabel 1 perlakuan yang diberikan tidak memberikan pengaruh nyata pada parameter pertumbuhan vegetatif berupa jumlah daun, tinggi tanaman, dan jumlah anakan. Jumlah daun yang dihasilkan 
Widianti, dkk : Respon Pembungaan Globba leucantha var. bicolor Holttum Terhadap Volume Pemberian Air dan Pupuk NPK....

tanaman Globba ini belum mencapai jumlah maksimalnya. (Takano dan Okada, 2003) menyatakan bahwa tanaman Globba ini dihabitat alaminya memiliki daun sejumlah 6-11 helai.

Tabel 1 Pengaruh Volume Pemberian Air dan Pupuk NPK Terhadap Pertumbuhan Vegetatif

\begin{tabular}{|c|c|c|c|}
\hline Perlakuan & Jumlah daun (helai) & $\begin{array}{l}\text { Rata-rata tinggi } \\
\text { tanaman }(\mathbf{c m})\end{array}$ & $\begin{array}{c}\text { Rata-rata jumlah } \\
\text { anakan }\end{array}$ \\
\hline A ( $100 \%$ KAT tanpa pupuk) & $7,33 \mathrm{a}$ & $45,33 \mathrm{a}$ & $1,67 \mathrm{a}$ \\
\hline $\mathrm{B}(100 \% \mathrm{KAT}+2 \mathrm{gram} /$ tanaman $)$ & 9,33 a & $41,30 \mathrm{a}$ & $3,33 \mathrm{a}$ \\
\hline $\mathrm{C}(100 \% \mathrm{KAT}+4 \mathrm{gram} /$ tanaman $)$ & 9,67 a & $48,17 \mathrm{a}$ & $6,00 \mathrm{a}$ \\
\hline $\mathrm{D}(80 \%$ KAT tanpa pupuk $)$ & 8,67 a & $46,97 \mathrm{a}$ & 0,67 a \\
\hline $\mathrm{E}(80 \% \mathrm{KAT}+2 \mathrm{gram} /$ tanaman $)$ & $10,00 \mathrm{a}$ & $51,93 \mathrm{a}$ & $2,67 \mathrm{a}$ \\
\hline $\mathrm{F}(80 \% \mathrm{KAT}+4$ gram $/$ tanaman $)$ & $9,33 \mathrm{a}$ & $51,57 \mathrm{a}$ & $2,00 \mathrm{a}$ \\
\hline G (60 \% KAT tanpa pupuk) & $8,00 \mathrm{a}$ & $46,50 \mathrm{a}$ & $1,33 \mathrm{a}$ \\
\hline $\mathrm{H}(60 \% \mathrm{KAT}+2 \mathrm{gram} /$ tanaman $)$ & 6,67 a & $37,93 \mathrm{a}$ & $2,67 \mathrm{a}$ \\
\hline I (60 \% KAT + 4 gram/tanaman $)$ & 7,67 a & $40,80 \mathrm{a}$ & $3,67 \mathrm{a}$ \\
\hline J (40\% KAT tanpa pupuk) & 8,00 a & $37,47 \mathrm{a}$ & $1,67 \mathrm{a}$ \\
\hline $\mathrm{K}(40 \% \mathrm{KAT}+2 \mathrm{gram} /$ tanaman $)$ & 9,33 a & $53,70 \mathrm{a}$ & $4,33 \mathrm{a}$ \\
\hline $\mathrm{L}(40 \% \mathrm{KAT}+4$ gram/ tanaman $)$ & $8,33 \mathrm{a}$ & $43,50 \mathrm{a}$ & $1,67 \mathrm{a}$ \\
\hline
\end{tabular}

Keterangan: Nilai rata-rata yang diikuti huruf sama pada setiap kolom yang sama menunjukkan tidak berbeda nyata pada DMRT taraf 5\%

Pada akhir pengamatan hampir seluruh perlakuan menunjukkan hasil rata-rata tinggi tanaman yang lebih rendah dari pada tinggi tumbuhan Globba yang tumbuh secara alami di habitat aslinya yaitu $52-59 \mathrm{~cm}$ (Pratiwi et al, 2012), Hal ini diduga menunjukkan adanya perubahan morfologi tanaman sebagai akibat domestikasi tanaman yang dilakukan (Utami, 2014). Sebagai tanaman hias yang akan dinikmati keindahan bunganya, ukuran tanaman yang terlalu tinggi akan berpengaruh terhadap nilai estetika yang ditunjukkan sebagai tanaman hias.

Tabel 2 Tahapan perkembangan perbungaan Globba

\begin{tabular}{|c|c|c|c|}
\hline Hari ke- & $\begin{array}{c}\text { Tahap } \\
\text { Perkembangan }\end{array}$ & Ukuran $(\mathrm{cm})$ & Keterangan \\
\hline 0 & $\begin{array}{l}\text { Pembentukan } \\
\text { bakal bunga }\end{array}$ & 0 & $\begin{array}{l}\text { Daun tanaman sudah tidak terbentuk dan digantikan dengan } \\
\text { pembentukan bakal bunga majemuk. }\end{array}$ \\
\hline 1 & $\begin{array}{l}\text { Munculnya } \\
\text { kuncup malai }\end{array}$ & $0,5-1,5$ & $\begin{array}{l}\text { Bakal malai bunga berwarna putih mulai muncul dari ujung } \\
\text { batang semu tanaman Globba }\end{array}$ \\
\hline $2-6$ & $\begin{array}{l}\text { Pemanjangan } \\
\text { malai }\end{array}$ & $2-5$ & $\begin{array}{l}\text { Malai bunga semakin bertambah panjang dan bakal bunga mulai } \\
\text { terlihat berdiferensiasi menjadi kuncup-kuncup bunga. }\end{array}$ \\
\hline $7-8$ & $\begin{array}{l}\text { Perkembangan } \\
\text { kuncup bunga }\end{array}$ & $7-10$ & $\begin{array}{l}\text { Kuncup - kuncup bunga mulai berkembang dari pangkal tangkai } \\
\text { majemuk dan berurutan hingga ke ujung tangkai. Satu persatu } \\
\text { kuncup mulai membentuk mahkota bunga yang masih } \\
\text { menggulung berwarna kuning pucat terbungkus selaput putih. }\end{array}$ \\
\hline $8-10$ & Bunga mekar & $10-12$ & $\begin{array}{l}\text { Bunga pertama Globba mulai mekar menyerupai angsa. Warna } \\
\text { oranye terlihat pada bagian anther appendages, labellum dan } \\
\text { lateral staminode. Sedangkan bagian lain seperti ovary, calyx, } \\
\text { corolla tube, dan filament berwarna putih. Saat bunga mekar, } \\
\text { stlyle akan menyembul keluar dari anther appendages untuk } \\
\text { melakukan polinasi pada waktu-waktu tertentu. }\end{array}$ \\
\hline $11-15$ & Bunga layu & $12-17$ & $\begin{array}{l}\text { Bunga mekar tidak serempak dalam satu malai, setelah mekar 1- } \\
2 \text { hari kemudian bunga akan layu dan gugur. Dalam satu } \\
\text { rangkaian bunga setiap tangkai bunga pada rangkaian bunga } \\
\text { dapat menghasilkan bunga mekar lebih dari satu kali. }\end{array}$ \\
\hline
\end{tabular}


Jumlah anakan yang muncul diduga merupakan hasil fotosintesis tanaman yang berlangsung. Hasil dari fotosintesis ini adalah fotosintat berupa protein dan karbohidrat yang akan digunakan sebagai bahan pertumbuhan tanaman (Sopandie, 2013). Proses fotosintesis yang berjalan maksimal memicu perkembangan tanaman dan munculnya tunas-tunas baru (Buntoro et al,. 2014). Hasil fotosintesis akan diedarkan keseluruh bagian tanaman berupa protein dan karbohidrat untuk bahan pertumbuhan (Sopandie, 2013).

\section{Fenologi bunga}

Visualisasi tahapan perkembangan bunga Globba berdasarkan penelitian dapat dilihat pada Gambar 1, uraian dari perkembangan bunga tersaji pada Tabel 2.

Bunga mulai muncul pada interval waktu 29-42 hst menunjukkan bahwa Globba leucantha memasuki fase generatifnya. Bunga terbentuk sebagai hasil dari proses fotosintesis yang terjadi pada tanaman. Saputri et al., menjelaskan bahwa fotosintat akan di translokasikan sesuai aktivitas tumbuhan yang sedang terjadi, salah satunya ketika proses reproduksi sedang berlangsung maka fotosintat ditranslokasikan menuju organ generatif untuk membentuk bunga.

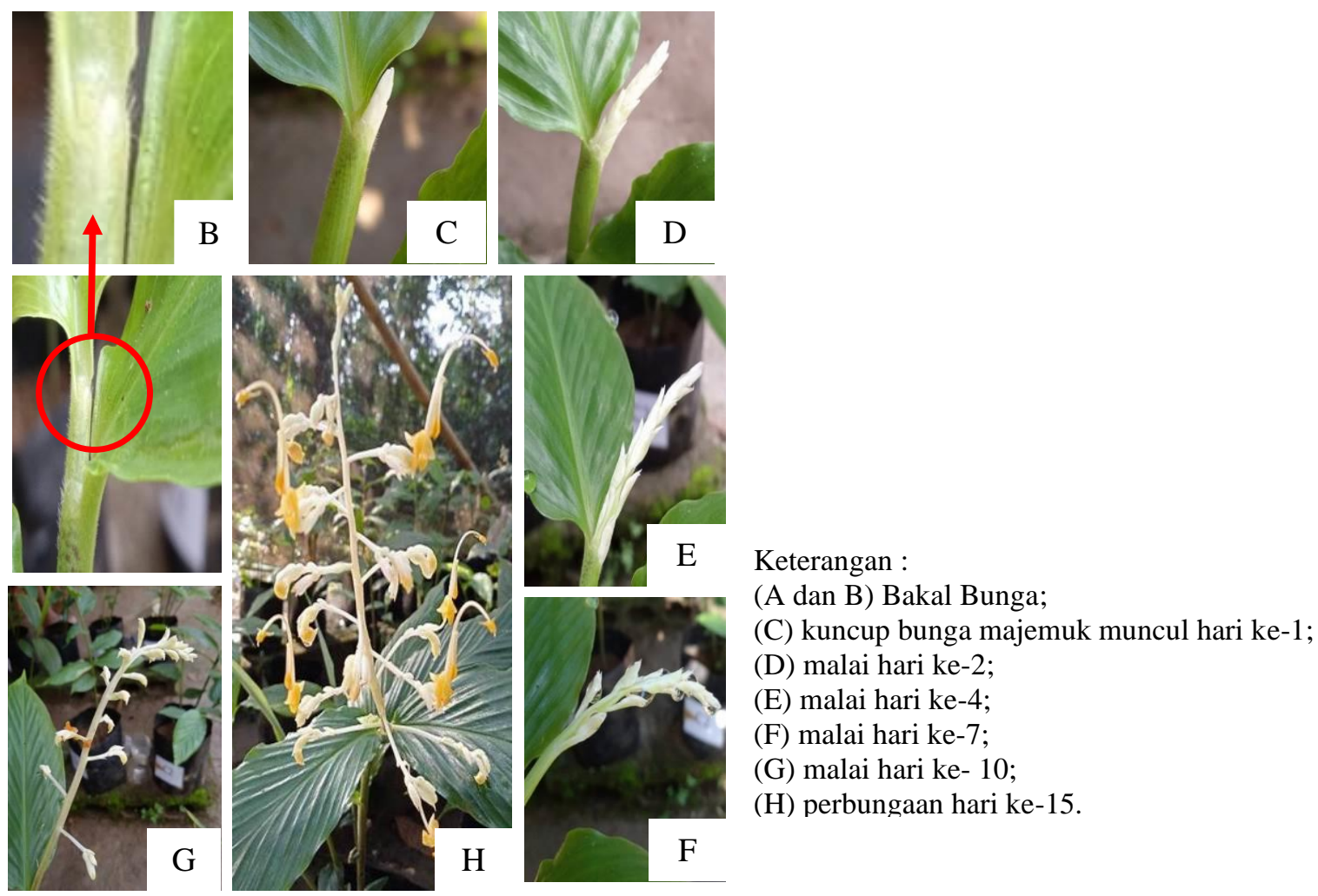

Gambar 1 Tahapan Perkembangan Bunga

\section{Panjang Malai (cm)}

Berdasarkan Tabel 1 diatas, pemberian volume air dan pemupukan NPK tidak memberikan pengaruh nyata terhadap panjang malai dan jumlah bunga per malai. Panjang malai terbaik ditunjukkan oleh perlakuan $\mathrm{C}$ (Pemberian volume air 100\% KAT + pupuk 4 gram/tanaman) namun tidak berbeda nyata dengan perlakuan G( pemberian air $60 \%$ KAT tanpa pupuk) dan perlakuan $\mathrm{K}$ (pemberian air $40 \% \mathrm{KAT}+$ pupuk 2 gram/tanaman). Hasil $(0,00)$ merupakan perlakuan yang tidak menghasilkan bunga. Tanaman yang belum membentuk bunga ini diduga masih memerlukan waktu untuk menyelesaikan fase vegetatifnya. Perlakuan $\mathrm{H}$ (60 \% KAT + 2 gram/ tanaman) dan L (40\% KAT + 4 gram/ tanaman) menunjukkan jumlah daun yang belum mencapai jumlah maksimal seperti ditunjukkan pada Tabel 1. Fase generatif tanaman Globba ini dimulai ketika helaian daun sudah berhenti terbentuk dan digantikan dengan munculnya kuncup bunga. Pada tanaman 
Widianti, dkk : Respon Pembungaan Globba leucantha var. bicolor Holttum Terhadap Volume Pemberian Air dan Pupuk NPK....

lain yang masih dalam family Zingiberaceae seperti kencur ( Kaempferia galanga) perbungaan muncul setelah terbentuk 2-3 daun dewasa dari ujung pseudostem saat tanaman berumur 3-4 mst (Silalahi dan Harmijatun, 2020). Selain itu, siklus hidup tanaman Globba sebagai tanaman budidaya masih perlu diteliti secara lebih lanjut. Pratiwi et al., (2012) menyatakan bahwa pada habitat alaminya Globba leucantha merupakan tumbuhan herba perennial, seperti family Zingiberaceae lainnya yang akan mengalami masa dormansi pada musim tertentu.

Tabel 3 Pengaruh Volume Pemberian Air dan Pupuk NPK Growmore Terhadap Parameter Pembungaan Globba Leucantha

\begin{tabular}{|c|c|c|}
\hline Perlakuan & Rata-rata Panjang malai (cm) & $\begin{array}{c}\text { Rata-rata jumlah bunga per } \\
\text { malai }\end{array}$ \\
\hline A ( $100 \%$ KAT tanpa pupuk) & $8,83 \mathrm{a}$ & $10,0 \mathrm{a}$ \\
\hline B ( $100 \% \mathrm{KAT}+2 \mathrm{gram} /$ tanaman $)$ & $5,00 \mathrm{a}$ & $8,0 \mathrm{a}$ \\
\hline $\mathrm{C}(100 \% \mathrm{KAT}+4 \mathrm{gram} /$ tanaman $)$ & 10,43 a & 16,7 a \\
\hline D ( $80 \%$ KAT tanpa pupuk) & $3,33 \mathrm{a}$ & $5,3 \mathrm{a}$ \\
\hline $\mathrm{E}(80 \% \mathrm{KAT}+2 \mathrm{gram} /$ tanaman $)$ & $6,67 \mathrm{a}$ & $11,3 \mathrm{a}$ \\
\hline $\mathrm{F}(80 \% \mathrm{KAT}+4 \mathrm{gram} /$ tanaman $)$ & $2,43 \mathrm{a}$ & $4,7 \mathrm{a}$ \\
\hline G (60\% KAT tanpa pupuk) & $10,27 \mathrm{a}$ & $22,0 \mathrm{a}$ \\
\hline $\mathrm{H}(60 \% \mathrm{KAT}+2$ gram/tanaman $)$ & $0,00 \mathrm{a}$ & $0,0 \mathrm{a}$ \\
\hline I (60 \% KAT + 4 gram/tanaman) & $3,37 \mathrm{a}$ & $8,0 \mathrm{a}$ \\
\hline J (40 \% KAT tanpa pupuk) & $0,00 \mathrm{a}$ & $0,0 \mathrm{a}$ \\
\hline K (40\% KAT+ 2 gram/tanaman $)$ & $9,2 \mathrm{a}$ & 24,0 a \\
\hline $\mathrm{L}(40 \% \mathrm{KAT}+4$ gram/tanaman $)$ & $0,00 \mathrm{a}$ & $0,0 \mathrm{a}$ \\
\hline
\end{tabular}

Keterangan : Nilai rata-rata yang diikuti huruf sama pada setiap kolom yang sama menunjukkan tidak berbeda nyata pada DMRT taraf $5 \%$ setelah dilakukan tranformasi $\sqrt{\mathrm{x}}+0,5$.

Globba leucantha var bicolor Holttum memiliki perbungaan bertipe terminal, Panjang malai yang belum maksimal ini diduga karena masih dalam proses pembentukan sehingga belum mencapai panjang malai yang maksimal. pembungaan tegak dengan panjang 3- $12 \mathrm{~cm}$ dan panjang total 14-21, $5 \mathrm{~cm}$ (Takano dan Okada, 2003). Panjang malai yang terbentuk merupakan hasil dari proses metabolisme yang dibantu oleh pemberian air dan unsur hara yang cukup (Gatabazi et al., 2019).

\section{Jumlah Bunga per Malai}

Berdasarkan Tabel 1 diatas, rata-rata jumlah bunga tertinggi diperoleh dari perlakuan $\mathrm{K}$ (pemberian air 40\% KAT + pupuk 4 gram/tanaman), tidak berbeda nyata dengan perlakuan G (pemberian air 60\% KAT tanpa pupuk) dan perlakuan A (pemberian air $100 \%$ KAT tanpa pupuk). Hasil $(0,00)$ merupakan perlakuan yang tidak menghasilkan bunga. Faktor genetik lebih banyak mempengaruhi jumlah bunga yang dihasilkan dibandingkan faktor lingkungan. Kondisi lingkungan di lokasi penelitian memiliki suhu yang berkisar antara 20,3-28, $7^{\circ} \mathrm{C}$, kelembaban udara $(48,2-92 \%)$ dan curah hujan rata-rata sebesar 325,5 mm/bulan. Kondisi ini sesuai dengan syarat tumbuh Globba yang dapat tumbuh baik pada suhu $18,5-21,3^{\circ} \mathrm{C}$, kelembaban udara 73,6 91\% dan curah hujan tinggi (Siagian, 2010).

\section{KESIMPULAN}

Perlakuan pemberian volume air dan pemupukan tidak memberikan pengaruh nyata pada panjang malai dan jumlah bunga yang dihasilkan. Perlu dilakukan penelitian lebih lanjut terkait volume pemberian air dan pupuk NPK Growmore terhadap pembungaan Globba leucantha meliputi waktu pemberian pupuk yang tepat, lama waktu dilakukan penelitian hingga muncul bunga seluruhnya serta penggunaan media tanam yang tepat 
Jurnal Penelitian Pertanian Terapan

untuk pertumbuhan Globba leucantha sehingga diperoleh sebuah paket teknologi budidaya tanaman hias Globba leucantha.

\section{DAFTAR PUSTAKA}

Abdurachman, A., Haryati, U. and Juarsah, I. (2005) Penetapan Kadar Air Tanah dengan Metode Gravimetrik.

Buntoro;, B.H., R. R. and Trisnawati, S. (2014) 'Pengaruh Takaran Pupuk Kandang dan Intensitas Cahaya terhadap Pertumbuhan dan Hasil Temu Putih ( Curcuma zedoria L)', Jurnal Vegetalika, 3(4), pp. 2939.

Gatabazi, A. et al. (2019) 'Evaluating Growth, Yield, and Water Use Efficiency of African and Commercial Ginger Species in South Africa', Journal Water, 11(548), pp. 1-20.

Halisah; (2013) Pengaruh Konsentrasi Pupuk Growmore dan Interval waktu terhadap Pertumbuhan dan Produksi Tanaman Kedelai (Glycine max L) ( Skripsi).

Jalil, M. ., Subandar, I. and Nurkiswa; (2016) 'Pengaruh Jenis Mulsa dan Pupuk NPK terhadap pertumbuhan dan produksi tanaman jahe merah (Zingiber officinale Roscoe)', Jurnal Agrotek Lestari, 2(1), pp. 6575.

National parks (2019) Globba leucantha Miq. Flora dan Fauna Web, 13 Agustus 2020.

Nontasit, N. . et al. (2015) 'Taxonomic Studies and Traditional Uses of Zingiberaceae in Khao Luang National Park, Nakhon si Thammarat Province, Thailand', Walailak Journal Agriculture Technology and Biological Sciences, 12(8), pp. 643-658.

Pangesti, F. D., Herlina, N. . and Suminarti, N. E. (2017) 'Respon Tanaman Sorgum (Shorgum bicolor L. Moench) pada Berbagai Jumlah dan Frekuensi pemberian Air', Jurnal Produksi Tanaman, 5(7), pp. $1151-1161$.

Petraglia, A. . et al. (2014) Effects of Nitrogen and Phosphorus supply on Growth and Flowering Phenology of the snowbud Graphalium supinum L. Journal Flora.

Phantong, P. . et al. (2018) 'Comparing Growth and Physiological responses of Globba schomburgkii Hook and Globba marantina L. under hydroponic and soil conditions’, Emirates Journal of Food and Agriculture, 22(1), pp. 1-8.

Siagian, S. (2010) Inventarisasi Zingiberaceae di Kawasan Agrowisata Hutan Taman Eden 100 Kabupaten Toba Samosir Sumatra Utara (Skripsi).

Silalahi, M. . and Harmijatun, Y. . (2020) 'Pembentukan Taruk ( Shoot) dan Pembungaan Kencur ( Kaempferia galanga L)', Jurnal Prolife, 7(2), pp. 120-133.

Sopandie, D. . (2013) Fisiologi Adaptasi Tanaman terhadap Cekaman Abiotik pada Agroekosistem Tropika. IPB Press.

Takano, A. . and Okada, H. (2003) 'Taxonomy of Globba (Zingiberaceae) in Sumatera, Indonesia. Osaka City University’, American Society of Plant Taxonomists, 28(3), pp. 524-546.

Ula, D. Q. ., Azizah, N. . and Suryanto, A. . (2019) 'Pembungaan Kembali Tanaman Mawar ( Rossa sp) sebagai tanaman Taman melalui Pemangkasan dan Pemberian Pupuk’, Jurnal Plantropika, 4(11), pp. 1-10.

Utami, D. W.; (2014) 'Pemanfaatan Asosiasi Lintas Genom (Studi Asosiasi Genom) dalam Pemuliaan Tanaman', Jurnal Litbang Pertanian, 33(4), pp. 141-148. 